\title{
OS KARAJÁ DE ARUANÃ-GO E SEUS TERRITÓRIOS RESTRITOS: biodiversidade reduzida, integridade abalada ${ }^{1}$
}

\author{
THE KARAJÁ ARUANÃ-GO OF RESTRICTED AND ITS TERRITORIES: \\ low biodiversity, integrity shaken
}

\section{EL KARAJA ARUANA-GO Y SUS TERRITORIOS RESTRINGIDOS: bajo la diversidad biológica, la integridad sacudida}

\author{
Sélvia Carneiro de Lima
}

\author{
Graduada em Geografia e mestranda pelo Programa de pesquisa e pós-graduação em Geografia do \\ Instituto de Estudos Socioambientais - IESA/UFG. Goiânia/GO. \\ Campus Samambaia (Campus II) - Goiânia-GO, CEP: 74001-970 \\ E-mail: selvia_lima@yahoo.com.br
}

\section{Resumo}

Quais são as estratégias de sobrevivência dos índios Karajá de Aruanã-GO diante da perda da biodiversidade do Cerrado e da fragmentação e redução de seus territórios? Essa é a questão central de discussão neste artigo. Os Karajá, ao longo dos séculos, viram seus territórios tradicionais reduzirem-se a três áreas fragmentadas e pressionadas pela pecuária e pelo turismo. A chegada dos primeiros colonizadores no território hoje conhecido por Goiás deu inicio ao processo que desencadeou a redução, fragmentação e perda dos territórios até então indígenas. A partir desse processo, atualmente, a fauna e a flora do Cerrado, um dos elementos básicos para manutenção da integridade física e cultural desses indígenas, foram se desvanecendo à sombra dos desmatamentos e de outras formas de degradação ambiental que assolam o município. Mergulhados, por um lado, na tradição que marca o rio Araguaia como o eixo central de sua cosmologia e, por outro, no ethos urbano de um município que atende as demandas do capitalismo global, aos Karajá cabe o enfrentamento dos inúmeros desafios a sua sobrevivência física e cultural. Diante disso, os Karajá têm articulado estratégias de desenvolvimento de novo significado para a sua produção artesanal e para o uso de seus territórios em um processo dinâmico que estabelece múltiplas trajetórias espaciais em busca dos recursos para a produção do artesanato destinado ao mercado. Nesta pesquisa priorizou-se a abordagem territorial pela via da discussão qualitativa, desenvolvida a partir de variados

\footnotetext{
${ }^{1}$ Este artigo resulta do projeto de pesquisa: Biotecnologia e a Gestão Participativa da Biodiversidade: Estudos de Caso de Instituições, Conhecimento Popular e Saberes Locais no Cerrado Brasileiro, apoio do Institut de Recherche et Developpement - IRD ( França) e do projeto: Apropriação do território e dinâmicas socioambientais no Cerrado:biodiversidade, biotecnologia e saberes locais, com recursos financeiros do $\mathrm{CNPq}$
} 
recursos teórico-metodológicos, cujo objetivo principal consistiu no diálogo com os sujeitos envolvidos.

Palavras-chave: biodiversidade. território. índios Karajá. Vale do Araguaia.

\begin{abstract}
What are the survival strategies of the Karaja indigenous people of Aruana-GO in face of the loss of biodiversity in the Cerrado and the fragmentation and reduction of their territories? This is the central discussion in this article. Over the centuries, the Karaja people have seen their traditional lands reduced to three fragmented areas, and farming and tourism continue to put pressure on them. The arrival of the first settlers in the territory, currently known as Goias, triggered the process of reduction, fragmentation and loss of indigenous territories. Because of this process, currently, the fauna and flora of the Cerrado - one of the basic elements for maintaining the physical and cultural integrity of indigenous peoples - have been vanishing in the shadow of deforestation and of other forms of environmental degradation that have plagued that county. Dwelling on the threshold of the tradition which sets Araguaia River as the main pillar of cosmology and of the ethos of an urban municipality that meets the demands of global capitalism, the Karaja people face a myriad of challenges to keep themselves alive, physically and culturally. In reason of that, the Karaja people have articulated strategies for developing new meanings to their craft production and to the use of their territory through a dynamic process that can offer multiple paths in the search for space resources and market for their handicraft production. In this research priority was given to territorial approaches and qualitative discussions which were developed from a rich variety of theoretical and methodological resources. The main objective was to establish dialogues with the individuals involved.
\end{abstract}

Keywords: biodiversity, territory, Karaja indigenous people, Vale do Araguaia.

\title{
Resumen
}

¿Cuáles son las estrategias de supervivencia de los indios Karajá de Aruanã-GO ante la pérdida de la diversidad biológica en el Cerrado y la fragmentación y la reducción de sus territorios? Este es el tema central en discusión en este artículo. A lo largo de los siglos, el pueblo Karajá ha visto sus tierras tradicionales reducirse a tres áreas fragmentadas y presionadas por la agricultura y el turismo. Con la llegada de los primeros colonos, en el territorio hoy conocido como Goiás, se inició el proceso que desencadenó la reducción, fragmentación y pérdida de los territorios indígenas. Por causa de este proceso, actualmente la fauna y la flora del Cerrado - uno de los elementos básicos para el mantenimiento de la integridad física y cultural de los pueblos indígenas - son una sombra que se desvanece con la deforestación y con otras formas de degradación ambiental que plagan el municipio. Divididos entre la tradición que marca el río Araguaia - como el principal pilar de la cosmología - y el ethos de un municipio urbano que responda a las exigencias del capitalismo global, el pueblo Karaja enfrenta numerosos retos para su supervivencia física y cultural. En razón de esto, el pueblo 
Karajá ha articulado estrategias para el desarrollo de un nuevo sentido a su producción artesanal y para la utilización de su territorio en un proceso dinámico que ofrezca varias rutas en la búsqueda de los recursos espaciales para la producción de artesanías para el mercado. En esta investigación, la prioridad fue la discusión cualitativa, desarrollada a partir de una rica variedad de recursos metodológicos y teóricos, cuyo objetivo principal consistió en establecer diálogo con los individuos participantes.

Palabras clave: biodiversidad, la tierra, indios Karajá, Vale do Araguaia.

\section{Introdução}

Viver numa aldeia indígena dentro de uma área urbana localizada em um dos pólos mais importantes do turismo e da produção de rebanho bovino de Goiás é um desafio. Sobreviver das atividades tradicionais de caça, pesca, coleta e roçados em um território diminuto, fragmentado e solapado pelo desmatamento com alagamentos anuais, é igualmente, um desafio. A sobrevivência dos índios Karajá de Aruanã-GO, no século XXI, constitui-se resumidamente nestes desafios.

A discussão dessa pesquisa tem como foco o povo Karajá que somam atualmente 216 indivíduos localizados no vale do Rio Araguaia, na região Noroeste do estado de Goiás, município de Aruanã. A relação estreita entre índios e Cerrado tem gerado para os primeiros um desafio de sobrevivência física e cultural à medida que o segundo tem sido solapado para dar lugar, em Aruanã, aos pastos para criação de gado

bovino. É na dinâmica do desmatamento intensificado que as pastagens são ampliadas e a biodiversidade reduzida.

A biodiversidade ao ser afetada abala a produção artesanal, atividade mais importante de sustento das famílias Karajá, tradicionalmente elaboradas a partir dos recursos naturais da fauna e flora. A redução da biodiversidade modifica os fundamentos da vida indígena e esses por sua vez reelaboram estratégias de sobrevivência. A produção artesanal, então ganha novos elementos tanto provenientes de outros biomas como da cultura não-indígena num processo criativo que revela as estratégias do grupo diante da ausência dos recursos naturais do Cerrado usados tradicionalmente nos objetos de sua cultura.

Assim, a redução da biodiversidade gerada pelo desmatamento no município de Aruanã, em torno de $80 \%$ (VALENTE, 2008), aliada a perda ao longo dos anos dos territórios tradicionais, atualmente reduzido a três áreas tem gerado inúmeros desafios a manutenção da vida indígena. É nesse viés que inserimos a base central de discussão 
dessa proposta balizada no seguinte questionamento: Quais as estratégias de sobrevivência dos índios Karajá de Aruanã diante da perda da biodiversidade e da fragmentação e redução dos seus territórios? Entende-se que para responder essa questão faz-se necessário compreender numa escala mais ampla a articulação de Goiás ao capital internacional impulsionado pelas decisões políticas e econômicas em nível nacional e estadual.

Partindo desta discussão, nesta pesquisa, priorizou-se a discussão pela via da abordagem territorial numa abordagem qualitativa. $\mathrm{O}$ trabalho de campo, $\mathrm{o}$ levantamento bibliográfico, as entrevistas, as rodas de conversa, o diário de campo foram algumas das bases teórico-metodológicas desenvolvidas.

$\mathrm{Na}$ primeira parte desse artigo foi considerado o contexto socioespacial dos Karajá e sua relação com o rio Araguaia, seu território tradicional. Na segunda parte discuti-se os aspectos econômicos do município de Aruanã, a pecuária e o turismo e os impactos sobre os Karajá e seus territórios. Em seguida, apresenta-se o Cerrado enquanto patrimônio genético, e as perdas da biodiversidade deste bioma no município de Aruanã. Finalmente, aborda-se a situação atual das Terras Indígenas em Aruanã, e as estratégias dos Karajá para sobreviverem diante dos desafios que lhes foram impostos, bem como as trajetórias socioespaciais desenvolvidas na busca pelos recursos destinados a produção do artesanato, uma das bases do sustento material do grupo.

\section{Os Karajá de Aruanã: existência e resistência}

Em função da facilidade de navegação no rio Araguaia, desde o século XVI, documentos históricos mencionam o contato entre os Karajá e os não-índios, o que torna a situação de exposição à cultura dita ocidental para além de quatro séculos (Lima Filho, 2006). Assim, os primeiros relatos sobre a localização desse povo aparecem no final desse século e os caracteriza como habitantes do baixo e médio curso do Araguaia. Essa datação representa a prova de que os Karajá nunca se afastaram daquilo que consideram seu território tradicional: o rio Araguaia. (TORAL, 1992).

O vínculo com o território tem origem no mito de origem que os apresenta como o "povo do fundo rio" que se constitui, portanto, o útero fértil de onde se originaram todos os Karajá. É o território da origem, do nascimento e do sentido da vida indígena. 
É nesse viés que é possível entender a relação profunda entre o Cerrado, com tudo que ele abarca, a fauna, a flora, a terra, as águas e os Karajá. Há um simbolismo que permeia as relações entre índios e Cerrado, entre seus elementos constitutivos e o desenvolvimento da vida neste território que tradicionalmente era indígena. O Araguaia, portanto, constitui-se o território material e simbólico onde identidade indígena e território se misturam.

Para os Karajá, portanto, o Araguaia e suas margens são permeados pelas histórias dos entes que se foram e que marcaram suas identidades nos territórios que são constantemente recriados e atualizados. Neste caso, o território é compreendido, conforme explicita Haesbaert (2005, p. 79), como uma “imbricação de múltiplas relações de poder, do poder mais material das relações econômico-políticas ao poder mais simbólico das relações de ordem mais estritamente cultural”.

Atualmente, a população Karajá no Brasil (composta pelos subgrupos Javaé, Xambioá e Karajá) soma quase 3.000 índios distribuídos em torno de 14 aldeias localizadas ao longo do rio Araguaia nos estados de Goiás, Pará, Tocantins e Mato Grosso, concentrados, sobretudo, na ilha do Bananal - TO (PIMENTEL SILVA, 2009). Espacialmente os "Buridina Mahãdu ou Karajá de Aruanã são o grupo mais meridional do território dos Karajá”. (TORAL, 1992, p.19). Esta dinâmica espacial das aldeias Karajá localizadas ao longo do vale do Araguaia no Domínio do Cerrado revela o vínculo identitário existente entre estes indígenas e seu território sagrado. Através dos longos anos adaptados a esse ambiente eles foram desenvolvendo, como estratégias de sobrevivência, técnicas de uso da biodiversidade aí existente.

Em Aruanã, desde o século XX, o Cerrado tem se constituído em um típico exemplo da degradação ambiental que tem assolado o território goiano, da década de 1970 em diante, quando seus solos ácidos tiveram o PH corrigido, transformando-se a partir daí, em um celeiro de produção de grãos no Brasil. É o reino da monocultura espacialmente concentrada na região Sudoeste do estado.

A região Noroeste, no mesmo período, é solapada pelas transformações das fitofisionomias típicas do Cerrado em extensas áreas de pastagens: é o reino da pecuária, que tem desde então substituído a cobertura natural por gramíneas, cujo objetivo principal destina-se a criação de milhares de cabeças de gado bovino. 
Além da pecuária, sobretudo a extensiva, o município destaca-se também como pólo de atração turística por desenvolver o chamado "Turismo de Natureza" - pesca esportiva e temporada de férias nas praias do Araguaia. O incentivo ao turismo em Aruanã tem gerado um fluxo migratório cada vez mais intenso acentuando as situações de degradação ambiental no município.

É nesse cenário que resistem os índios Karajá coexistindo espacialmente com a urgência do tempo acelerado no ethos urbano e as atividades econômicas do mundo contemporâneo responsáveis tanto pela perda de seus territórios e da biodiversidade, entendida como a diversidade genética, ecológica e de espécies (BENSUSAN, 2002), básicos para manutenção e reprodução física e cultural.

As decisões e os rearranjos econômicos e políticos nas escalas municipal, estadual, nacional e internacional que ocorreram no século XX são a base para entender as dinâmicas atuais que intercedem sobre Aruanã, os territórios indígenas e a biodiversidade.

Esta dinâmica que insere Goiás num contexto de articulação política e econômica mais ampla provocou profundas mudanças culturais, sociais e espaciais no território goiano, afetando diretamente a biodiversidade e o modo de vida dos Karajá, índios do Cerrado. Entender a configuração atual destes territórios e suas implicações culturais, sociais e econômicas bem como suas transformações socioespaciais, passa pela compreensão das dinâmicas que articularam o mundo numa teia global, denominada globalização.

É com a chegada dos tori $^{2}$ no vale do Araguaia que se inicia a desarticulação da base da vida Karajá. É no território, até então indígena, que tem inicio diversas atividades ligadas à mineração, a navegação, a pecuária e posteriormente, na segunda metade do século XX, o turismo. Nesse caminho o que ocorreu a partir do estabelecimento do aglomerado urbano, em 1850, foi um crescimento contínuo do município, hoje Aruanã, sobre o território tradicional destes índios que desde o século XIX foi tornando-se cada vez mais restrito em função da chegada dos não-índios, bandeirantes, militares, religiosos, colonos.

Após inúmeras e sucessivas perdas atualmente o território dos índios Karajá de Aruanã encontra-se restrito a três Terras diminutas e descontinuas que são: Terra

\footnotetext{
${ }^{2}$ Palavra utilizada pelos Karajá para referirem-se aos "não-indígenas".
} 
Indígena Karajá Aruanã I - aldeia Buridina, Terra Indígena Karajá Aruanã III - aldeia Aricá, ambas localizadas no município de Aruanã-GO, e Terra Indígena Karajá Aruanã II, localizada no estado do Mato Grosso, município de Cocalinho, na margem esquerda do Rio Araguaia. (Figura, 1).

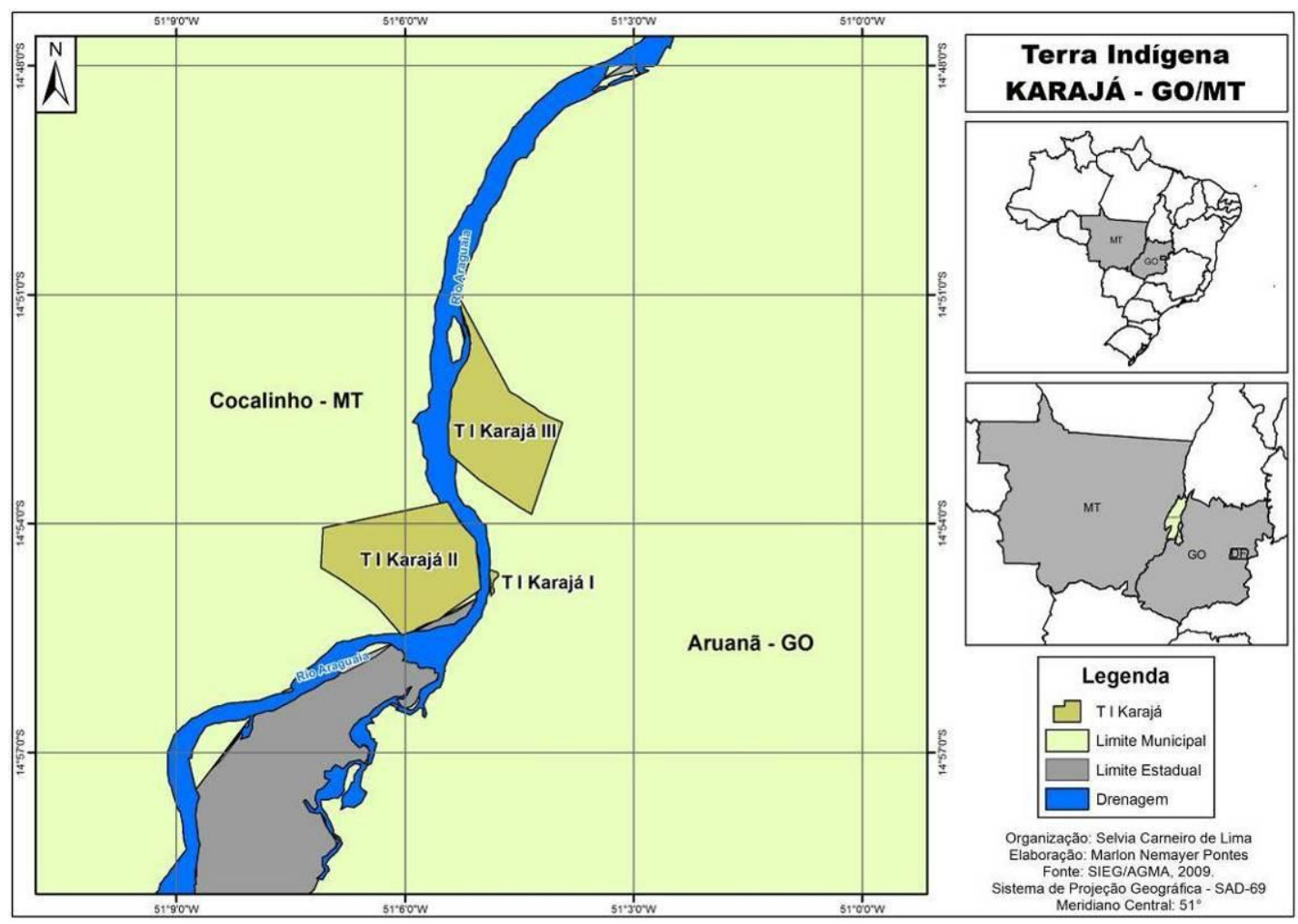

Figura 1: Localização das Terras Indígenas Karajá de Aruanã I, II e III - GO/MT

É neste território diminuto e fragmentado que se encontra uma das contradições dos Karajá neste século. De um lado, o território constitui-se a base segura para reprodução da vida, a segurança material de sua sobrevivência física e cultural, e por outro lado, representa a área do confinamento humano, destituída, em função da dimensão reduzida e das situações de degradação, dos recursos naturais da biodiversidade do Cerrado necessários para garantir o sustento físico e cultural do grupo.

Em nível nacional a expansão das fronteiras, objetivo nacional de dominar, explorar e povoar, o interior do Brasil, o chamado "sertão", e o crescimento da atividade pecuária no município de Aruanã, desencadearam um processo de redução do território e desestruturação do sistema produtivo Karajá, que é baseado nas atividades de caça, pesca, coleta e agricultura e caracterizados por migrações sazonais. (ROCHA, 1998; 
RIBEIRO, 1996). Além da supressão de várias práticas culturais como as festas de Aruanã e do Hetohoky.

O surgimento de Aruanã sobre o território Karajá no século XIX se deu com muitos conflitos armados, o que provocou a morte e migração de vários Karajá para outras aldeias. Os indígenas que permaneceram viram a maior parte de seus territórios serem vendidos. Deste modo, expropriados do território, a situação de miséria, alcoolismo, prostituição e doenças, era a marca do grupo até o início da década de 1970, quando a Fundação Nacional do Índio - FUNAI inicia pontualmente ações assistencialistas após um longo período de abandono por parte do órgão indigenista. (PORTELA, 2007).

Nos anos de 1986 e 1987 tem inicio as visitas de técnicos da FUNAI à aldeia Buridina $^{3}$ onde são elaborados vários relatórios da situação dos indígenas que coaduna com articulação efetiva de luta pela delimitação e retomada da Terra Indígena Karajá I.

Essa luta é concretizada na década de 1990, com a demarcação das atuais três áreas para posse permanente dos Karajá de Aruanã, ficando assim definida: Terra I GO, possui 14 hectares, é local de moradia onde se localiza a aldeia Buridina; Terra II MT, com 893 hectares, é usada para caça, pesca e coleta; Terra III - GO, com 705 hectares, onde se localiza a aldeia Arica, é local de moradia, e também utilizada para cultivos prolongados, criação de gado leiteiro, coleta e caça. Em síntese, há três Terras Indígenas Karajá e duas aldeias: a Buridina na Terra I, centro de Aruanã, e a Arica na Terra III, que se localiza em torno de $6 \mathrm{~km}$ da primeira.

Esta retomada do território e sua regularização jurídica representaram para os Karajá de Aruanã uma marca importante na luta pela dignidade. O crescimento populacional do grupo ganha impulso com a migração de parentes atraídos pela conquista dessas terras. Como citado anteriormente, a população Karajá de Aruanã é de 216 índios, dos quais, 180 localizam-se na aldeia Buridina e 36 na aldeia Arica. Há ainda 29 indígenas desaldeados no município de Aruanã $\tilde{a}^{4}$ (FUNASA, 2008)

A restrição do território tradicional a áreas com limites estabelecidos e demarcados representa na prática um confinamento espacial humano. É o que mostra a

\footnotetext{
${ }^{3}$ Constitui-se a aldeia mais antiga com vinte e duas casas. Localiza-se no centro da cidade de Aruanã, na margem do Rio Araguaia. A aldeia Aricá localiza-se na Terra Indígena Karajá III, dista em torno de $6 \mathrm{~km}$ da primeira, com seis casas construídas e mais dezessete em construção.

${ }^{4}$ Dados obtidos na unidade da FUNASA em Aruanã-GO. Trabalho de campo fevereiro de 2009.
} 
situação da aldeia Buridina, única área que restou na margem do Araguaia para a moradia Karajá. Lima filho (2006), afirma que ao longo do tempo em função do aumento populacional de não-indígenas em Aruanã, os Karajá foram obrigados a viver apenas nessa aldeia do barranco, não sendo mais possível o deslocamento das habitações de acordo com o período de estiagem e chuva como no passado.

Hoje todas as Terras Indígenas em Aruanã já estão demarcadas e homologadas, no entanto, de acordo com os Karajá, existe na maior parte da Terra I o uso por parte de não-índios o que causa maior adensamento das famílias dentro da área onde se localiza a aldeia Buridina. Segundo eles a atividade dos tori nessa área é constante e não tem sido fiscalizada.

Visitamos uma das residências luxuosas localizadas dentro da área I que havia sido transformada em pousada no segundo semestre de $2008^{5}$. Nessa área há uma diversidade de elementos como estacionamento de carros e guarda-barco; ruas pavimentadas; mansões de veraneio; praça, uma escola estadual e outros. ${ }^{6}$ Em entrevista um dos Karajá, afirma que, essa é uma área conflituosa e disputada por localizar-se na margem do Rio Araguaia no centro de Aruanã lócus de intensa valorização imobiliária e pelo poder dos atores envolvidos.

Dentre os atores que disputam essa área há deputados federais e "grupos de grande poder econômico em Goiás, tais como, Thermas do Rio Quente, TV Anhanguera, Agroquímica Produtos Agropecuários [...]”. (PORTELA, 2006, p. 91). Um técnico da FUNAI, relata que esta situação tem sido perpetuada porque ainda falta o pagamento das indenizações o que significa que legalmente os Karajá retomaram a Terra I, mas parte dela ainda não pode ser usada.

No caso da Terra Karajá II - MT, de acordo o atual cacique, ela não é usada como área de moradia por permanecer a maior parte do ano alagada no período chuvoso - outubro a março. Embora reconheça que esta área seja importante para a manutenção da vida dos Karajá, um dos artesãos da aldeia Buridina é incisivo quanto à situação atual da terra destinada a eles: "Não serve pra plantar, porque alaga tudo. Na parte que não é alagada é muito longe para fazer roça. Quando está seco, as praias ( sic) têm dono, fica cheia de barracas e tem placas que fala reservada para fulano e beltrano".

\footnotetext{
${ }^{5}$ Trabalho de campo ocorrido em Aruanã-GO, no primeiro semestre de 2009.

${ }^{6}$ Todas as informações foram obtidas através de entrevistas e questionários feitos em trabalhos de campo, entre o segundo semestre de 2008 e primeiro de 2009 em Aruanã - GO.
} 
Este processo de redução do território Karajá às três Terras demarcadas é fruto de um processo histórico iniciado no século XVIII com as atividades dos não-índios, bandeirantes, religiosos, militares, colonos que representaram o braço da coroa portuguesa nas frentes pioneiras de dominação dos territórios do sertão. Os resultados desses embates provocados pela resistência indígena à dominação foram permeados por confrontos violentos com aprisionamento, escravização e massacre dos índios. (ROCHA, 1998).

[...] a partir do período colonial, o jogo e o contexto político-econômico da sociedade nacional vão determinar, geograficamente, as formas de ocupação, impondo limites e condições, enfim, administrando o território do Estado como um todo. Assim, relações entre as sociedades indígenas e a sociedade nacional (a partir do século XVII) passam a se operar a partir do pressuposto da existência de uma base territorial fixa para os índios, seja ela qual for. E será esse o mecanismo adotado pelo Estado para conferir ou reconhecer a identidade étnica de um grupo indígena. (LADEIRA, 2008, p. 84).

Nascem os espaços de confinamento indígena regulados pelo Estado. Ladeira (2008, p. 84), considera ainda que "os enfoques sobre o território indígena se inserem nos diversos contextos nacionais (político, histórico, econômico e social)".

Em relação a essa situação de descontinuidade dos territórios Karajá, Portela (2006, p. 92), afirma que existe uma "situação de complementaridade entre as três áreas, já que a comunidade "desenvolve sua vida econômica, social e ritual num mundo constituído de três ambientes distintos [...]”".

Em Aruanã, o que não difere de outros territórios indígenas em todo o país, os tori chegaram e permaneceram, alterando pela apropriação do território, a cultura e a organização socioespacial dos Karajá, bem como o uso da língua indígena, e os rituais. As atividades econômicas que se sucederam ao longo dos séculos hoje caracterizadas pela pecuária e pelo turismo representam processos importantes para compreender a perda da biodiversidade no município e sua degradação ambiental. As extensas áreas de pastagens aliadas às ações predatórias de caça e pesca que comprometem a biodiversidade local são alguns exemplos das dinâmicas atuais que interferem na relação entre os Karajá e o Cerrado.

\section{Entre bois e Jet-Sky: Aruanã no século XXI}


Barbosa, Teixeira Neto; Gomes (2005, p. 49), consideram que "O território goiano-tocantinense atual foi regionalmente constituído sobre os antigos territórios dos povos e tribos indígenas que aqui viviam antes da chegada dos colonizadores". Com essa declaração os autores iniciam a discussão sobre a formação territorial dos estados constituídos hoje por Goiás e Tocantins. É neste cenário que tem inicio o povoado de Leopoldina, hoje Aruanã (1943), sobre o território tradicional Karajá, como mencionado anteriormente. Fundada em março de 1850, como um presídio militar, tinha como principal objetivo povoar a região, dar suporte as navegações e combater os indígenas (ROCHA, 1998). Somente em 1958 Aruanã passa a condição de município.

Localizada na margem direita do Rio Araguaia na confluência com o Rio Vermelho, em área de Domínio de Cerrado ${ }^{7}$, Aruanã encontra-se na latitude $14^{\circ} 55^{\prime} \mathrm{S}$, longitude $51^{\circ} 04^{\prime}$ W e altitude de 252,73 m. Dista 310 km de Goiânia, capital de Goiás, pela GO-164, e faz parte da mesorregião denominada Noroeste Goiano e da microrregião Rio Vermelho ${ }^{8}$ limitando-se com os municípios de Nova Crixás, Matrinchã, Mozarlândia, Araguapaz, Britânia e Cocalinho - MT. Possui uma área total de 3.050,303 km² (SEPLAN, 2007), e população estimada de 6.500 habitantes apresentando então baixa densidade demográfica, em torno de 1,72 hab/km² (IBGE, 2007).

Em relação à zona urbana, os dados obtidos nos trabalhos de campo, mostram que, do ponto de vista da estrutura comercial a cidade apresenta-se frágil. Há uma única agência bancária e uma casa lotérica. O comércio local é restrito e possui uma pequena quantidade de lojas, supermercados, bares, restaurantes, hotéis e pousadas. Há um único hospital e três escolas públicas, sendo uma exclusivamente indígena. Não há feiras, escolas particulares, Universidades, centros profissionais, nem associações expressivas. Os produtos agrícolas que abastecem a cidade, inclusive hortifrutigranjeiros, são oriundos da capital, Goiânia, indicando que há deficiência na produção familiar no município.

\footnotetext{
${ }^{7}$ Expressão usada para designar o espaço onde há predomínio de uma determinada vegetação, neste caso aqui, o Cerrado, embora possam ocorrer outros tipos de vegetação.

${ }^{8}$ De acordo com o IBGE (1969), Goiás insere-se na região Centro-Oeste sendo divido estatisticamente em cinco mesorregiões, dezoito microrregiões e 246 municípios. Aruanã localiza-se na microrregião Rio Vermelho que pertence a mesorregião Noroeste com total de 13 municípios. Disponível em: http://www.seplan.go.gov.br/sepin/viewcad.asp?id_cad=5101\&id_not=1. Acessado em: 09/06/2009.
} 
Essa é uma situação contraditória quando cruzamos a informação com os dados da prefeitura municipal que registram anualmente o quantitativo de 600 mil turistas ${ }^{9}$ no município. Além do turismo, Aruanã possui expressividade na atividade pecuária. São mais de 200 mil cabeças de gado bovino, constituindo-se no maior criadouro de bois da microrregião do Rio Vermelho (SEPIN, 2007). É nesse contexto espacial entre exportação de carne bovina e ronco de Jet-Sky que imperam diferentes interesses fazendo do Cerrado e suas águas uma arena de disputas.

O mapa de cobertura do solo em Aruanã (Figura 2) mostra que mais de $70 \%$ da área do município encontra-se desmatada.

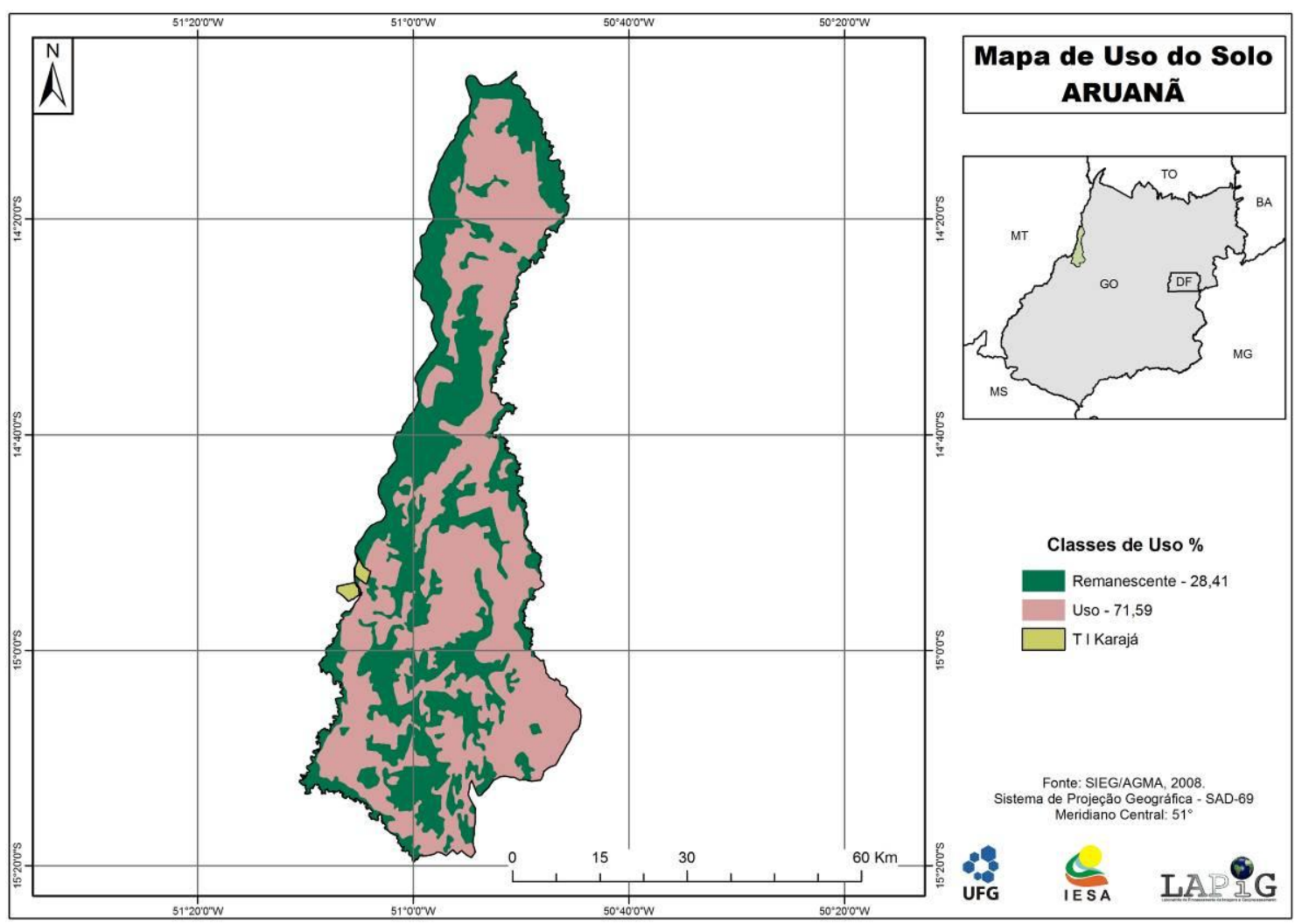

Figura 2: Mapa de cobertura do solo em Aruanã-GO

\footnotetext{
${ }^{9}$ Dados fornecidos a autora em dezembro de 2008 pela Prefeitura Municipal de Aruanã - GO. Vale considerar que em sites que abordam o turismo nas cidades brasileiras, os números de turistas que visitam Aruanã, variam entre 90 e 150 mil pessoas por ano.
} 
O mapa de cobertura do solo em Aruanã (Figura 2) mostra ainda que o percentual de remanescente da vegetação original não chega a 30\%. Em relação a estes dados da cobertura vegetal em Aruanã um dos professores Karajá mostra-se ainda mais pessimista quanto à atual situação do Cerrado no município, e afirma:

Cerrado? Não tem mais Cerrado aqui não. Já acabou tudo. Quando ainda se acha pequi, por exemplo, é o pequi de vara, porque os tori não respeita o tempo da fruta e manda a vara para derrubar os pequi que nem madurou. Já acabou os bichos, os peixes, o Cerrado, tudo, tudo. O que tem é muito gado aqui.

A percepção dos indígenas quanto à situação da perda do Cerrado não é balizada por dados estatísticos, mas pela experiência de quem usa e (re)conhece o lugar. Neste caso a observação indígena e os dados obtidos demonstram que a biodiversidade tem sido assolada pela ocupação humana, sobretudo pela atividade pecuária.

Em relação às dinâmicas socioespaciais impregnadas no território através da pecuária alguns historiadores apontam que até o século XIX os Karajá mesmo com perdas e conflitos ainda viviam sob certa autonomia, mesmo porque o Araguaia só em nossos dias seria realmente integrado na economia nacional, através da ocupação dos campos marginais por criadores de gado. É essa a atividade que modifica intensamente a situação socioespacial dos Karajá, ou seja, a consolidação da atividade pecuária no Noroeste Goiano trás uma desconfiguração dos territórios indígenas que nem mesmo o ciclo da mineração conseguiu.

$\mathrm{Na}$ década de 1970 as fazendas tradicionais cederam "lugar para a grande propriedade voltada para a pecuária moderna - as S.A. do campo". (BARBOSA, TEIXEIRA NETO, GOMES, 2005, p. 69). Nessa região, de acordo com os autores, ao longo da GO-164, a chamada Estrada do Boi, as cidades e a demografia pode-se dizer que possui fluxo menor do que o fluxo de boi.

Barreira (1997), ao pesquisar as dinâmicas econômicas do Noroeste goiano considera que a década de 1960 marca a ocupação da pecuária de corte como um fenômeno até então interno e considera que as alterações espaciais mais significativas se processaram na região da "Estrada do Boi" a partir da estruturação econômica assentada na pecuária de corte. A pecuária tornar-se cada vez mais volumosa na década de 1970 em diante nos municípios de Aruanã, Porangatu, São Miguel do Araguaia, Crixás, Mundo Novo de Goiás, Nova Crixás, Mozarlândia e Nova América. 
A autora considera ainda que essa atividade se desenvolveu com êxito por utilizar pouca mão-de-obra e pouco investimento, por ser uma atividade extensiva, por existir áreas propícias as pastagens e pelo gado se auto-transportar. Para ela a integração dessa região, via pecuária, a economia estadual e nacional foi concretizada sem considerar as populações locais e o Cerrado.

É com base na lucratividade econômica da região que tem se trocado a roupagem do Cerrado pelas pastagens destinadas ao sustento das boiadas na região do vale do Araguaia. A valorização das terras foi ocorrendo à medida que essas foram sendo incorporadas pelo trabalho numa ordem semelhante a apresenta por Motta (2004): desmatamento, agricultura de subsistência, pastagem e gado.

O Plano de Metas criado pelo governo de Juscelino Kubitschek, na década de 1950, marcou a integração do território goiano a economia nacional. A abertura de estradas e a construção de Brasília foram instrumentos de conquista interna do território nacional e estratégia política administrativa para a ocupação de Goiás. Nas décadas de 1970 e 1980 a região Noroeste vivenciou um momento de expansão da urbanização com a implantação de estrada que alcança o Rio Crixás e os municípios de Mozarlândia e Aruanã. (BARRERA, 1997). É neste período, como vimos anteriormente, que ocorre a duplicação do rebanho bovino e o conseqüente aumento da disputa pela terra nessa região.

A atividade pecuária se consolida e coloca atualmente a microrregião do Rio Vermelho como o $2^{\circ}$ maior produtor de gado em Goiás. Em 1999 a produção de gado bovino foi de 200 mil cabeças, em 2005 de 232.500, e em 2007 foi de 245.850 mil (SEPLAN, 2009). Estes dados colocam Aruanã no primeiro lugar no ranking dos maiores produtores da microrregião Rio Vermelho, confirmando-o como um dos maiores produtores de rebanho bovino do estado de Goiás.

Além da produção de gado o município também produz, dentre outros, suínos 3.250 cabeças, e aves - 7.430 cabeças. (SEPLAN, 2007).

A valorização das terras gerada pela demanda dos fazendeiros, e agregação de valor à terra pelos pecuaristas, constitui-se situação importante para compreender as pressões exercidas sobre o território dos Karajá de Aruanã. No entanto, não são apenas estes os agentes de pressão e valorização das terras em Aruanã. O desenvolvimento econômico como possibilidade ganhou expressão nas ações políticas do Estado para 
promover a paisagem do rio Araguaia como cenário de lazer. A partir da década de 1990, o fluxo de turistas em Aruanã avoluma-se, principalmente, no período de clima mais seco do ano, quando surgem as praias em decorrência da diminuição do volume de água do Araguaia.

De acordo com o atual cacique Karajá o interesse dos turistas por Aruanã vem desde 1940, mas a partir de 1970, é que o turismo se concentra com maior intensidade. Ele narra com "ar melancólico" como a relação com os não-índios foi alterando a rotina deles com o ambiente: "Um dia fomos pegar melancia na praia, ali onde é a Terra II, e um turista falou: não é pra pegar. Falamos pra ele que nós tínhamos plantando, e que era nossa. Ele respondeu: larga aí. Isso é nativo não é de vocês. Desse momento em diante fomos parando de plantar."

A relação entre índios e território ganha outra restrição com a ocupação dos turistas em Aruanã. Nas décadas seguintes a intensidade do fluxo turístico aumentou, sobretudo em função do papel do marketing promovendo o turismo estadual. Estas atividades econômicas, sobretudo a pecuária tem sido responsáveis pela perda da biodiversidade do Cerrado em Aruanã.

Perguntamos então: Qual a biodiversidade que se desvanece diante da perda do Cerrado em Aruanã? Qual a importância do Cerrado para a manutenção da vida indígena e não-indígena? A resposta a estas questões são basilares nesta proposta de compreender a relação entre vida indígena, Cerrado, e desenvolvimento das atividades capitalistas no município de Aruanã.

\section{Cerrado: patrimônio genético, patrimônio cultural}

A relação estabelecida ao longo de anos de adaptação ao meio natural pelas comunidades tradicionais constitue-se fator fundamental para manutenção da biodiversidade. (DIEGUES, 2000). Daí concordamos com Barbosa (2002, p. 350) quando afirma que "no estudo das populações humanas de economia simples, centrada na caça e coleta, a compreensão da cobertura vegetal pode-se constituir num elemento fundamental para vislumbrar processos culturais desenvolvidos por essas comunidades." 
No caso do Cerrado, Barbosa (2002) considera que desde 11 mil anos já havia atividades ininterruptas de tribos de caçadores e coletores no Planalto Central Brasileiro. Assim, "compreender as estratégias de exploração ambiental adotadas e consequentemente captar elementos que propiciem o conhecimento dos tipos de planejamento utilizado". (BARBOSA, 2002, p. 350) ao longo de milhões de anos é importante para identificar a importância dos sujeitos indígenas como "guardiões do Cerrado".

Neste viés, ainda que de maneira sucinta, faz-se necessário trazer a discussão as características deste Bioma. Segundo Ferreira (2003, p. 11), o Cerrado é:

[...] uma formação tropical constituída por vegetações rasteira, arbustiva e árvores formada, principalmente, por gramíneas coexistentes com árvores e arbustos esparsos, ou seja, englobando os aspectos florísticos e fisionômicos da vegetação, sobre um solo ácido e relevo suave ondulado, recortada por uma intensa malha hídrica, formando uma paisagem única e diferenciada de savana, portanto, um Bioma único (FERREIRA, 2003, p.11).

Constitui-se um domínio fitogeográfico do tipo Savana Tropical; a maior do mundo em área contínua. Ocorre no Brasil e em partes do Paraguai e Bolívia. Ocupa quase a quarta parte do território nacional, sendo o segundo maior bioma brasileiro estendendo-se por uma área de um pouco mais de 2 milhões de $\mathrm{km}^{2}$, que corresponde a 23,92\% do território nacional, abrangendo nove estados brasileiros que são: Minas Gerais, São Paulo, Goiás, Tocantins, Bahia, Maranhão, Mato Grosso, Mato Grosso do Sul, Piauí e o Distrito Federal. (Figura 3). 

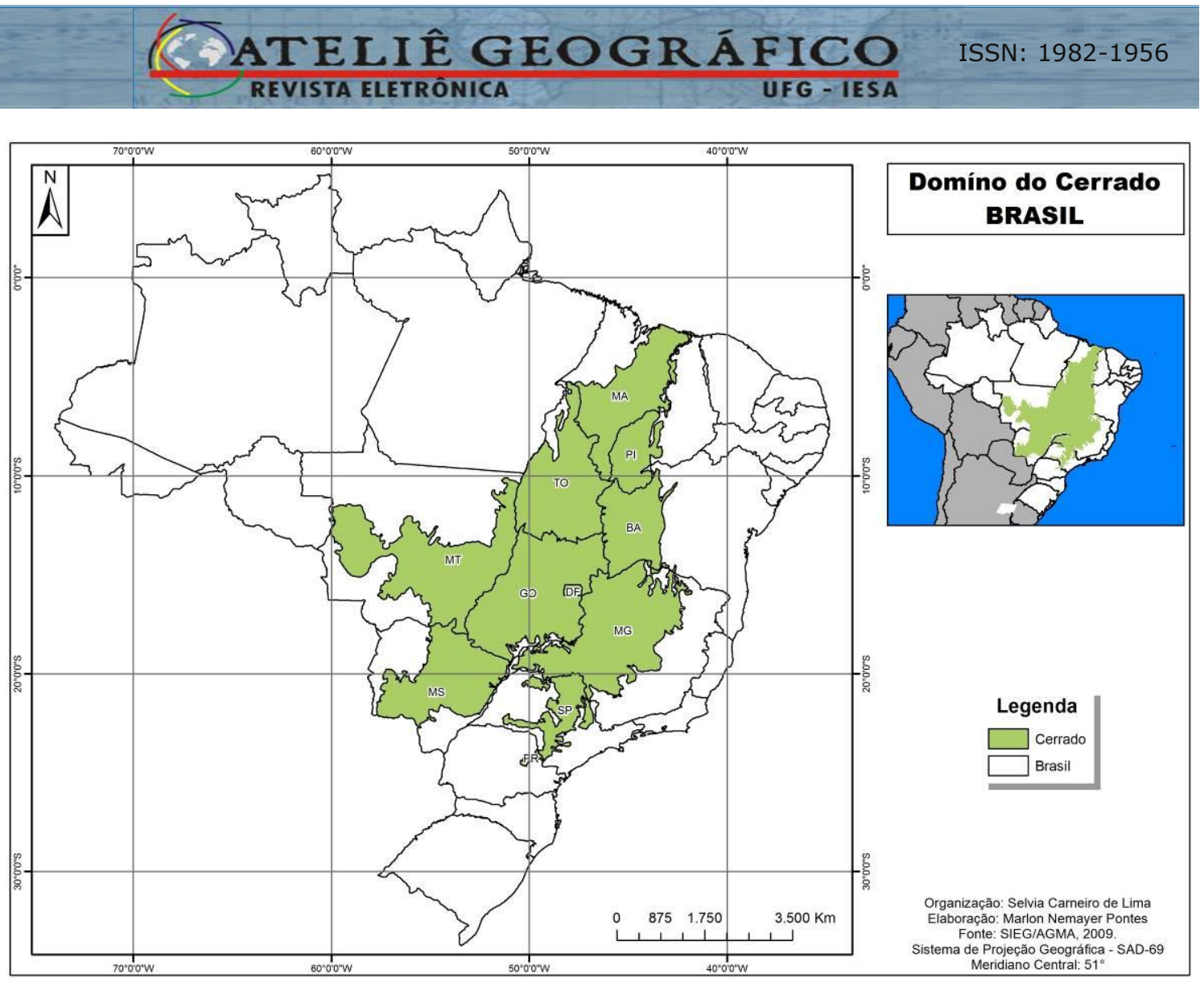

Figura 3: Domínio do Cerrado no Brasil

O Domínio do Cerrado é caracterizado por uma variedade de fitofisionomias. Há campos onde praticamente não há árvores, nem arbustos como o campo limpo e outros com alguns arbustos e árvores esparsas, o campo sujo, o campo rupestre e o campo cerrado. Há também florestas como as matas ciliares e de galerias (BENSUSAN, 2002, p. 18) e vegetação de ambientes alagadiços como os buritizais das veredas. Em relação a esse amplo leque de ambientes concordamos com Oliveira (2005, p. 178) que compreender a constituição dos diferentes "tipos de vegetação é um elemento importante no entendimento da biodiversidade dos ambientes."

Em relação à composição dos solos do Cerrado estes se apresentam ricos em ferro e alumínio e deficientes de outros minerais. O clima predominante é o Subtropical Semi - úmido caracterizado pela sazonalidade em duas estações bem definidas: verão úmido e inverno seco. A hidrografia é composta por uma extensa rede de nascentes, córregos e rios de fundamental importância para o Brasil, sendo considerado o "berço das águas" por comportar as nascentes das três maiores bacias hidrográficas da América Latina: a amazônica (Araguaia-Tocantins) que tem $78 \%$ de suas nascentes no Cerrado, a 
do Paraná-Paraguai que possui $48 \%$, e a do São Francisco que dispõe de quase $50 \%$ de seu volume de água proveniente do Cerrado.

A diversidade biológica é estimada em torno de mais de 320 mil espécies, das quais a fauna apresenta mais de 837 espécies de aves, muitas delas só se reproduzem nessa região. Os mamíferos somam 161 espécies. Os morcegos, que são importantes agentes polinizadores, totalizam em torno de 30 espécies, os répteis são em torno de 120 e os anfíbios mais de 150, sendo 45 espécies endêmicas. Além de várias espécies de roedores, microorganismos e fungos. (PINTO; DINIZ-FILHO, 2005).

Os autores consideram que entre as mais de 10.000 espécies de plantas do Cerrado, 4.400 são endêmicas, o que representa $1,5 \%$ de toda a flora mundial. Já as espécies animais apresentam também endemismo, embora num percentual menor. Essa diversidade faunística está associada à diversidade de ambientes, mencionado anteriormente, pois permite que ocorram tanto animais adaptados a ambientes secos quanto a ambientes úmidos. (BARBOSA, 2008). Essa riqueza biológica e genética do Cerrado, aliada à degradação intensa, o coloca juntamente com a Mata Atlântica entre os 25 hotspots do mundo.

Uma abordagem do Cerrado enquanto Bioma, parece-nos um caminho viável para compreender como os Karajá produzem sua existência nesse território. De que maneira esses indígenas foram se apropriando dessa biodiversidade e desenvolvendo um modo de vida próprio.

Pensar o Cerrado no vale do Araguaia como lócus da vida indígena é entender que água, terra, fauna e flora, adquiriram ao longo da história escrita no território um significado de vida em sentido duplo, é tanto o sustento físico, como espiritual do grupo, ou dito de outra maneira, constitui-se tanto a base material quanto a base

simbólica de sua existência. É o que nos ensina alguns índios Karajá10: “O rio e a terra é minha mãe"; "O rio é o meu sangue, sem ele nenhum Karajá existiria"; "O rio, o peixe Aruanã, a terra é mais do que o que vemos, são entidades espirituais também”. É esse Cerrado e sua biodiversidade que tem sido tocado e reduzido pelas ininterruptas ações antrópicas.

\section{A biodiversidade reduzida}


Segundo Valente (2008), ${ }^{11}$ a área primitiva do Cerrado no município era de 295.281 ha. Em 2008 a área não ultrapassava 112.100 ha (36,7\%), enquanto a área desmatada era de 183.181 (60\%). Dados um pouco mais otimistas que os apresentados anteriormente no mapa da figura 2 (p.12).

Valente (2008) afirma que a Cobertura da terra no município de Aruanã, é constituída por vegetações como: Campo Cerrado, Cerrado típico, Cerradão e Floresta de Galeria, área desmatada, massa de água e bancos de areias (praias). As áreas e porcentagens dessas classes de cobertura da terra estão representadas no Quadro 1 a seguir:

Quadro 1 - Cobertura da terra em Aruanã-GO, 2008

\begin{tabular}{|c|c|c|}
\hline Classes & Área (ha) & $\%$ \\
\hline Desmatamento & $183.181,00$ & 60 \\
\hline Floresta de Galeria & $45.273,00$ & 15 \\
\hline Cerradão & $29.684,00$ & 9,7 \\
\hline Campo Cerrado & $21.083,00$ & 7 \\
\hline Cerrado & $16.060,00$ & 5 \\
\hline Corpos d'água & $9.026,00$ & 3 \\
\hline Bancos de areia & 854,00 & 0,3 \\
\hline Total & $305.161,00$ & 100 \\
\hline
\end{tabular}

Fonte: Valente, 2008

Org. Lima, 2009

O desmatamento é tão intenso em Aruanã que já avançou, em várias propriedades rurais, sobre as áreas protegidas por lei (Área de Preservação Permanente APPs). Cerca de 1/4 dessas áreas no município já foram destruídas e, segundo Valente, avança sobre as Florestas de Galeria. A pesquisa mostra ainda que em 2008 as APPs somavam 51,646 ha (margem de rios, córregos e nascentes, dunas, serras e morros)

\footnotetext{
${ }^{10}$ As narrativas descritas neste trabalho foram obtidas em entrevista durante trabalho de campo em Aruanã-GO, nos meses de janeiro e março de 2009.

${ }^{11}$ Pesquisa desenvolvida por Dr. Cidney Rodrigues Valente em 2008, no município de Aruanã-GO. Os objetivos foram de mapear o desmatamento da vegetação do Cerrado em 2008 e nos últimos 8 anos (entre 2000 e 2008) e os recursos hídricos superficiais (lagos e rios). O resultado desse trabalho foi concedido ao Dr. Eguimar Felício Chaveiro e a mestranda Sélvia Carneiro de Lima, no Instituto de Estudos SócioAmbientais-UFG, através de entrevista gravada em 02/10/2009.
} 
correspondentes as fitofisionomias, Cerrado, Campo Cerrado e Floresta de Galeria. As áreas de reserva Legal somavam 59.056 ha.

Entre 2000 e 2008 foram desmatados no município, 29.162 ha de vegetação nativa do Cerrado que correspondem as fisionomias: Campo Cerrado, Cerradão, Cerrado e Floresta de Galeria, como mostra o Quadro 2.

Quadro 2- Desmatamento em Aruanã-GO, 2000-2008

\begin{tabular}{|c|c|c|}
\hline Fisionomias & Área (ha) & $\%$ \\
\hline Campo Cerrado & $16.113,00$ & 55 \\
\hline Cerradão & $8.176,00$ & 28 \\
\hline Cerrado & $3.793,00$ & 13 \\
\hline Floresta de Galeria & $1.080,00$ & 4 \\
\hline Total & $29.162,00$ & 100 \\
\hline \multicolumn{2}{|c|}{$\begin{array}{r}\text { Fonte: Valente, 2008 } \\
\text { Org. Lima, 2009 }\end{array}$}
\end{tabular}

Conforme mostra o Quadro 2 a vegetação de Campo Cerrado teve o maior percentual de redução, acima de 50\%, durante o período de 2000 a 2008. Deste modo, excluindo as APPs, o município apresenta apenas 60.454 de remanescente do Cerrado o que coloca a situação de desmatamento no valor máximo definido por lei de $80 \%$ de corte raso.

No mapa da cobertura do solo (Figura 2, p. 12) a área destinada à pecuária em Aruanã corresponde a mais de $70 \%$ do total do município. Diante desses dados é possível considerar que em Aruanã a grande alavanca do desmatamento e da destruição da biodiversidade constitui-se a atividade pecuária. Fato ilustrado na narrativa de um professor Karajá: "usamos uma determinada madeira do Cerrado para fazer remo, não sei dizer o nome dela em português, agora ela não existe mais porque os fazendeiros derrubaram tudo para fazer cerca nas fazendas".

Em relação aos recursos hídricos, Valente (2008), afirma que do total de 570 lagos classificados como perenes e intermitentes, no município, 237 secam completamente no mês agosto, ou seja, 41,6\% tornaram-se intermitentes nos últimos oito anos em função do avanço do desmatamento em suas margens. Para Valente (2008) não há dúvida de que a perda dos lagos é resultado da ação intensa do desmatamento e do não respeito ao mínimo exigido pela legislação, como o caso das APPs. 
Valente (2008), aponta ainda que uma das principais conseqüências do desmatamento é a interferência direta sobre os recursos hídricos do município, a perda dos locais de reprodução de espécies da fauna, o aumento da taxa de evaporação dos lagos e rios, a redução da quantidade e qualidade de chuva na região.

A morte dos lagos interfere também diretamente na dieta Karajá, pois estes ambientes são importantes para a reprodução da tartaruga, fonte alimentar tradicional desses indígenas. A perda dos locais de reprodução aliada à pesca predatória foi apontada pelos Karajá como os principais fatores da quase extinção do réptil no município.

Em escala mais ampla a ocupação do Cerrado e o estrangulamento dos territórios dos povos indígenas e de outras populações tradicionais, como os Cerradeiros, Vazanteiros e Geraizeiros (ALMEIDA, 2005), se deu financiado pelo poder público cujo intuito principal era de colocar o Planalto Central no circuito internacional da produção agropecuária. É o que afirma a autora:

\begin{abstract}
[...] a ideologia da Marcha para o Oeste estimulou a ocupar os sertões e a fazer coincidir a fronteira política com a fronteira econômica. Em Goiás, a política de integração pode ser reconhecida, [...] na construção de Goiânia no prolongamento da Estrada de Ferro na década de 1930 [...] e na implantação de uma rede viária. Isso estava em consonância com o Plano de Metas (1956), que teve como objetivo espacial a construção de Brasília, associada à implantação da rodovia Belém-Brasília e ao propósito de interiorização do capital. (ALMEIDA, 2005, p. 340).
\end{abstract}

Percebe-se que a situação de degradação do Cerrado gerada pela implantação das atividades econômicas, anteriormente mencionadas, não se constitui apenas realidade do município de Aruanã, mas é um modelo adotado pelo Estado para dominar as extensas áreas de Cerrado no Brasil. Deste modo, articulando o Planalto Central Brasileiro à dinâmica econômica internacional através das atividades agropecuárias.

Qualquer interesse que não coadune com esse modelo de desenvolvimento não é interessante ao Estado. É nesse viés que se pode entender a situação atual das terras destinadas aos índios Karajá em Goiás: “picotada, diminuta” e desmatada.

\title{
Terra Indígena Karajá: reduzida, fragmentada, assolada
}

Além da redução e fragmentação do território indígena, os Karajá apontam que as áreas que lhes foram destinadas apresentam problemas que inviabilizam mais ainda o 
desenvolvimento de projetos de subsistência destinados à comunidade, tais como, o desmatamento intenso já existente na Terra Indígena III anterior a demarcação (Figura 4); os alagamentos que ocorrem na Terra Indígena II e III que inviabilizam o plantio de roças e a coleta na maior parte do ano.

Afirmam ainda que dentro da Terra III a prefeitura de Aruanã iniciou uma Estação Elevatória de Esgoto que, embora, embargada deixou como resultado uma grande área desmatada dentro da Terra Indígena. Além do desmatamento e dos alagamentos anuais ainda há as marcas do inicio da construção desse aterro sanitário.

A figura 4 apresenta o uso do solo nas Terras Karajá. A Terra II apresenta-se a mais preservada sendo utilizada como área de caça, pesca e coleta uma vez que não é possível a produção de roçados por causa do alagamento da área no período chuvoso e pelo uso intenso dos turistas no período seco.

De acordo com funcionários da FUNAI há um projeto sendo negociado entre o SESI e a Associação Indígena dos Karajá de Aruanã, para desenvolver a prática do turismo ecológico nessa área. Através de assessoria especializada a FUNAI pontua que o objetivo é encontrar meios de dar suporte aos índios para sobreviverem no mundo globalizado com base em sua cultura e seus valores e usando os recursos naturais da terra que possuem. 

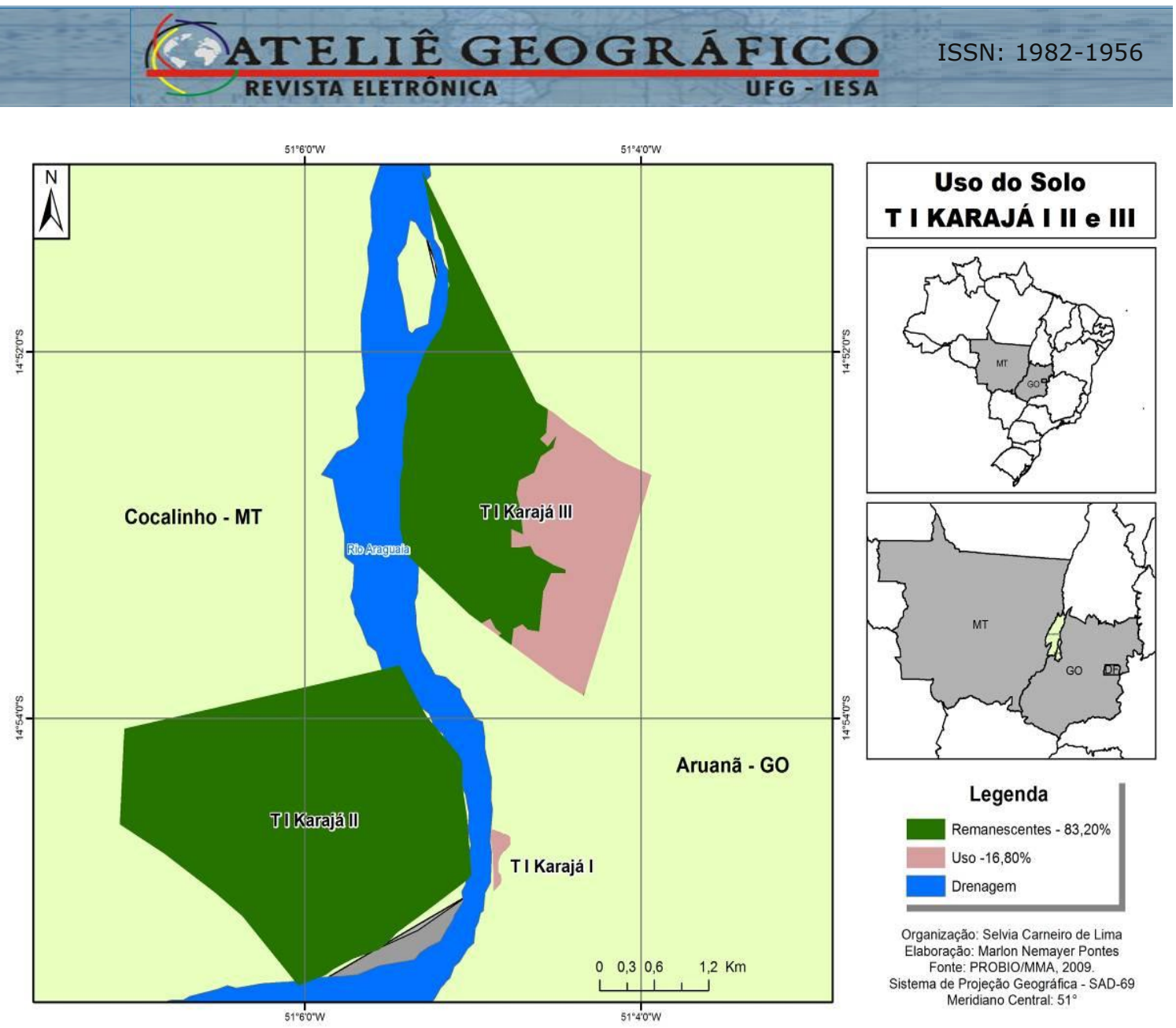

Figura 4: Cobertura do solo nas Terras Indígenas Karajá Aruanã I, II e III

Como não há legislação que ampare o turismo em Terras Indígenas, um dos técnicos da FUNAI, relata que será desenvolvido um projeto com "ética e bom-senso", cujo objetivo é dar suporte aos Karajá de Aruanã nos seus projetos de sustentabilidade, pois segundo ele a Terra II possui vários lagos que, associado aos aspectos culturais dos indígenas, podem viabilizar sustento econômico para as famílias que em muitos casos "chegam a passar fome", sintetiza.

$\mathrm{Na}$ Terra Indígena III, em 2008, foi iniciado algumas pequenas roças implementadas pelos indígenas com assessoria da FUNAI. Nessa área há também criação de gado leiteiro, adquiridos com recursos da FUNAI, cujo objetivo é o fornecimento de leite para as famílias Karajá.

São ações desenvolvidas pelos Karajá na busca por alternativas que lhes garanta desenvolvimento físico e cultural diante das situações de cerceamento territorial e perda dos recursos do Cerrado. 


\section{Trajetórias socioespaciais: alternativas criativas}

O contato entre índios e não-índios impulsionou uma intensa transformação cultural e linguiística dos Karajá de Aruanã-GO. Durante as décadas de 1980 e 1990 houve no Brasil um movimento de auto-afirmação étnica que promoveu avanços significativos para os povos indígenas em relação ao direito a diferença no respeito do uso de suas línguas e valorização de suas culturas. Em Aruanã os Karajá acompanharam este movimento, inicialmente, embrenhando-se na luta pela retomada de suas terras que coadunou com outras iniciativas de revitalização da língua e da cultura Karajá.

O movimento de resistência se deu em parceria com instituições como universidades, Secretaria de Educação do Estado de Goiás e FUNAI.

O projeto de Educação e Cultura Indígena Cacique Maurehi ${ }^{12}$ constituiu-se um dos movimentos de resistência e de auto-afirmação étnica. Uma das ações mais importantes desse projeto, de acordo com os indígenas, foi o deslocamento de vários "parentes" de outras aldeias para a aldeia Buridina com objetivo de ensinar aspectos da cultura Karajá como as pinturas, o artesanato em cerâmica, palhas e plumarias, as danças, os cantos e a contação de histórias.

Além do fortalecimento da educação indígena através da parceria com outras aldeias, a educação escolar indígena constituiu-se também um dos focos da luta Karajá para assegurar que crianças e jovens conheçam sua própria cultura e ao mesmo tempo sejam preparados para a vida competitiva no mercado de trabalho. Estes são os desafios da educação escolar indígena no mundo globalizado articular tradição indígena e os saberes da ciência dos não-índios.

A busca da qualidade e reconhecimento da importância dessa escola para a educação das crianças e jovens levou à ampliação da oferta de vagas e dos turnos de funcionamento no ano letivo de 2009. Foram oferecidos nesse ano atendimento nos três turnos, oferecendo desde a Educação Infantil até a Educação de Jovens e Adultos - EJA. A diretora da escola garante que a procura pela educação na escola indígena neste ano

\footnotetext{
${ }^{12}$ Desenvolvido e coordenado pela Faculdade de Letras - UFG, em parceria com os indígenas e outras instituições como a FUNAI e a SEE-GO. Foi criado o Museu Cacique Maurehi, para comercializar o artesanato dos indígenas dentro da aldeia Buridina e a Escola Indígena Cacique Maurehi com educação bilíngüe.
} 
se deu até mesmo por parte dos não-indígenas. Para ela isso é o resultado do movimento de afirmação da identidade do grupo.

A construção do Museu, onde funciona a loja de artesanato, representou outra página da luta Karajá para apoiar e incentivar a produção do artesanato indígena local consistindo não apenas como elemento de retorno econômico para os artesãos, mas ponto de valorização e revitalização da cultura Karajá.

A produção do artesanato, de acordo com os Karajá, representa a principal fonte econômica das famílias. Os turistas neste sentido são bem vistos por representarem mercado de escoamento dessa produção. O atual cacique afirma que o Museu é muito importante para os Karajá, pois "garante a ajuda para o sustento da casa e ensina a cultura às crianças”.

Além do artesanato, há na aldeia o comércio de peixes, de dentes de jacaré, boto e a produção e venda de móveis de madeira, atividades importantes de sustento de várias famílias Karajá.

A busca dos Karajá pelos recursos naturais usados na produção artesanal apresenta uma trajetória espacial ampla. Esses recursos são oriundos tanto das Terras II e III como adquiridos em Goiânia, na Cidade de Goiás, e de outras aldeias Karajá, principalmente as localizadas no estado do Tocantins, de hippies que comercializam em Aruanã, coletados em fazendas próximas e uma série de outras localidades.

A figura 5 mostra alguns dos recursos naturais da fauna e flora utilizados pelos Karajá na produção artesanal que são coletados nas Terras Karajaj ${ }^{13}$. No Quadro 1 apresentamos ainda o detalhamento do uso e dos locais de obtenção de alguns dos recursos naturais utilizados.

A produção artesanal revela o hibridismo cultural formado na situação de contato interétnico. Os Karajá produzem o artesanato a partir dos recursos que conseguem obter. É o caso, por exemplo, dos colares, brincos, tornozeleiras e outros, elaborados com sementes de açaí, oriundos da Floresta Amazônica, e adquiridos no comércio em Goiânia ou de hippies que vão a Aruanã vender produtos diversos.

$\mathrm{Na}$ falta das sementes do Cerrado para produção das tornozeleiras, pulseiras, e outros, utilizam-se também de diversos materiais produzidos de plástico e resinas

\footnotetext{
${ }^{13}$ Este mapa síntese não foi elaborado com ambição de esgotamento dessas informações, apenas como recurso visual para facilitar a compreensão dos deslocamentos desses indígenas na coleta dos recursos utilizados na produção do artesanato.
} 
adquiridas em lojas de aviamentos de Goiânia. Assim vão mesclando os elementos da cultura indígena ressignificados de acordo com as possibilidades de acesso aos recursos naturais e artificiais. Segundo o cacique, "temos que fazer este artesanato que não é totalmente tradicional porque nos falta (sic) os recursos naturais para usar".

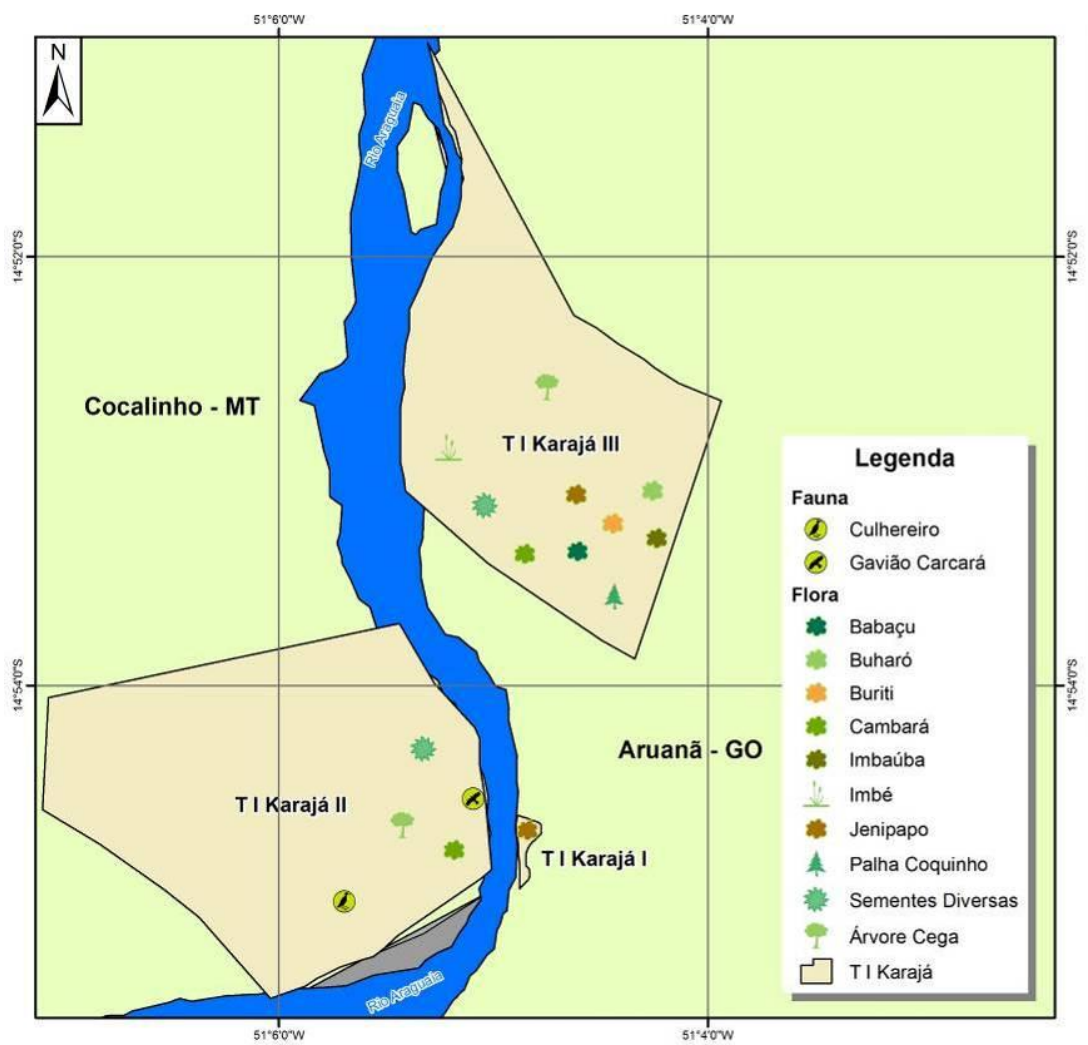

\section{Recursos Naturais T I KARAJÁ - GO/MT}

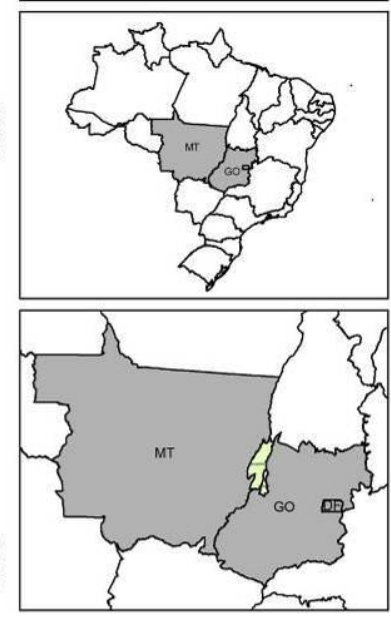

Organização: Selvia Carneiro de Lima Elaboração: Marlon Nemayer Pontes Fonte: SIEG/AGMA, 2009. Sistema de Projeção Geográfica - SAD-69
Meridiano Central: $51^{\circ}$

Figura 5: Recursos naturais obtidos nas Terras Indígenas Karajá Aruanã 
Quadro 3: Alguns recursos da flora do Cerrado utilizados pelos Karajá de Aruanã-GO

\begin{tabular}{|c|c|c|c|c|c|}
\hline Família & $\begin{array}{c}\text { Nome } \\
\text { Científico }\end{array}$ & $\begin{array}{c}\text { Nome } \\
\text { Popular }\end{array}$ & Uso & $\begin{array}{c}\text { Ambiente } \\
\text { ocorrência }\end{array}$ & $\begin{array}{r}\text { Local de } \\
\text { obtenção }\end{array}$ \\
\hline Rubiacea & $\begin{array}{c}\text { Genipa } \\
\text { americana, } \mathrm{L}\end{array}$ & Jenipapo & $\begin{array}{l}\text { Pintura corporal e } \\
\text { em utensílios; } \\
\text { remo }\end{array}$ & Mata & $\begin{array}{c}\text { Terra I e } \\
\text { III }\end{array}$ \\
\hline \multirow{3}{*}{ Palmae } & $\begin{array}{l}\text { Mauritia } \\
\text { vinifera }\end{array}$ & Buriti & $\begin{array}{l}\text { Produção de } \\
\text { bolsa, chapéu, } \\
\text { cestos, animais, } \\
\text { esteiras, peneiras, } \\
\text { saias, brincos }\end{array}$ & $\begin{array}{l}\text { Veredas e } \\
\text { ambientes } \\
\text { alagadiços }\end{array}$ & Terra III \\
\hline & $\begin{array}{l}\text { Orbignya } \\
\text { martiana, } \\
\text { Barb. Rodr. }\end{array}$ & Babaçu & $\begin{array}{l}\text { Bola, pomba, } \\
\text { peixe, mochila, } \\
\text { espanador, sacola, } \\
\text { cesto masculino } \\
\text { (broto), óleo do } \\
\text { côco }\end{array}$ & Mata & Terra III \\
\hline & Syagrus, sp. & $\begin{array}{l}\text { Coqueirin } \\
\text { ho-do- } \\
\text { campo }\end{array}$ & $\begin{array}{l}\text { Folha: Espanador, } \\
\text { bolsa, sacola }\end{array}$ & $\begin{array}{l}\text { Cerrado e } \\
\text { Campo }\end{array}$ & Terra III \\
\hline $\begin{array}{c}\text { Cucurbitacea } \\
e\end{array}$ & Citrullus, sp. & Melância & $\begin{array}{c}\text { Produção de } \\
\text { colares e outros } \\
\text { adornos } \\
\end{array}$ & $\begin{array}{l}\text { Campo e } \\
\text { Cerrado }\end{array}$ & $\begin{array}{c}\text { Terra II e } \\
\text { III }\end{array}$ \\
\hline Moraceae & $\begin{array}{l}\text { Cecropia } \\
\text { adenopus, } \\
\text { Mart. }\end{array}$ & Embaúba & Cordoarias: rede & $\begin{array}{l}\text { Matas } \\
\text { Ciliares }\end{array}$ & Terra III \\
\hline Bixaceae & $\begin{array}{c}\text { Bixa orellana, } \\
\text { L. }\end{array}$ & Urucum & $\begin{array}{c}\text { Corante para } \\
\text { pintura em } \\
\text { utensílios }\end{array}$ & $\begin{array}{l}\text { Mata e } \\
\text { Matas } \\
\text { Ciliares }\end{array}$ & Terra I \\
\hline $\begin{array}{c}\text { Caesalpinoid } \\
\text { eae }\end{array}$ & $\begin{array}{l}\text { Erythrina } \\
\text { reticulata, } \\
\text { Presl. }\end{array}$ & Mulungu & Colares, brincos & $\begin{array}{l}\text { Mata e } \\
\text { Matas } \\
\text { Ciliares }\end{array}$ & Terra II \\
\hline
\end{tabular}

Fonte: Dados etnográficos. Trabalho de campo em Aruanã-GO. Fev/2009; Barbosa, 2002.

Elaboração: Lima, 2009.

A venda da arte Karajá se torna um "elemento agregador num contexto de tensão em que o grupo mantém com a sociedade”. (MOTTA, 2004, p.77). Para Ratts (2009, p. 42) "Um grupo indígena que passou por transformações forçadas aceleradas pelo contato com a sociedade brasileira e com as relações capitalistas faz uso da mudança cultural para falar de si mesmo". É uma resposta do grupo à dinâmica que lhes foi imposta e revela uma adaptação ao momento atual onde as atividades tradicionais de caça, pesca, coleta e agricultura já não são mais suficientes para suprir as necessidades do grupo. 
A prestação de serviços - serventes, pedreiros, empregadas domésticas, garçons, etc, ocupa também grande parte da mão-de-obra indígena. Há ainda funcionários públicos temporários como professores(as), merendeira, zeladora, secretaria, motorista; há aqueles que sobrevivem com a ajuda do governo através de aposentadorias e dos recursos do Programa Bolsa Família, por exemplo. Estas representam algumas das atividades desenvolvidas pelos Karajá para sustentarem-se. Nas palavras do cacique Karajá: "temos que fazer muitas coisas agora para atender o modelo dos tori que nos foi imposto. São as roupas, os sapatos, esse tanto de remédio, e os materiais da escola das crianças. Tudo precisa de dinheiro.”.

\section{Uma boneca, duas bonecas... várias bonecas: a cultura ressignificada}

Os Karajá são tradicionalmente excelentes ceramistas. Constituem-se no único povo indígena do Brasil a produzir boneca em cerâmica como brinquedo para criança. As mulheres Karajá produzem tradicionalmente seis modelos dessas peças e vão, desde o preparo do barro, até a fase final da produção, ensinando-as os aspectos da cultura Karajá. Tradicionalmente todo o processo de produção das bonecas é educativo.

Dentre as peças produzidas na cultura material Karajá, essas bonecas apresentam destaque. Isto porque, de acordo com antropólogos, este é o único povo indígena conhecido no Brasil que elabora boneca em cerâmica como brinquedo para crianças. De acordo com o cacique, atualmente, a Universidade Federal de Goiás procura meios de registrá-las junto ao Instituto do Patrimônio Histórico e Artístico Nacional - IPHAN.

As bonecas representam na atualidade um dos exemplos da adaptabilidade do grupo ao mercado, sobretudo o turístico. A mercantilização da cultura material através da comercialização dessas peças traz um novo sentido para a boneca, que passa a ter neste contexto mais um significado: o de troca. Isto se constitui mais um dos exemplos das mudanças culturais provocadas tanto pela situação de contato interétnico quanto pelas perdas dos recursos naturais em Aruanã.

De acordo com uma das artesãs Karajá, tradicionalmente, as bonecas são moldadas a partir da mistura do barro e do pó da cinza da árvore Cega Machado, após a secagem são pintadas com tintas elaboradas a partir do jenipapo (preto) e do urucum (vermelho). Segundo ela, atualmente a matéria-prima existente no município não apresenta mais condições de ser utilizada como o caso da coleta do barro 
impossibilitada pela construção de uma olaria que revolveu o barro misturando-o com outros elementos, tornando-o impróprio para o uso. A solução foi comprar esse recurso de outros municípios como a Cidade de Goiás. Em relação à pintura das bonecas, ela afirma que em muitos casos é mais utilizada a tinta industrializada, pela dificuldade atual em obter as tintas naturais.

A modelagem das bonecas também ganhou nova estrutura na adaptação para o mercado. Os modelos tradicionais eram moldados sem os braços e atualmente estas peças praticamente não são mais produzidas desta maneira. As peças atuais em sua maior parte são moldadas com os braços, pois de acordo com a artesã os "turistas gostam mais". Outra modificação foi à criação de novos modelos das bonecas até mesmo com cinzeiros no alto da cabeça.

Para atender a demanda do mercado hoje são produzidas vários modelos das bonecas Karajá. Essa adequação ao mercado representa a força do símbolo mercantil que ao adentrar as representações indígenas (re)elabora e (re)ssignifica a cultura indígena.

\section{Considerações Finais}

A adaptação ao ambiente foi desenvolvida pelos Karajá na relação com seu território tradicional, o Cerrado, ao longo de vários séculos. O surgimento da cidade sobre o território indígena os inseriu no ethos urbano. É aí, nestes territórios superpostos que (co)existem cultura indígena e não-indígena numa relação marcada por diferentes interesses de uso e apropriação do território. É nesta dinâmica que os Karajá vão construindo sua existência desenvolvendo mecanismos tanto de resistência, quanto de adaptabilidade, gerada pela situação de contato, no Domínio do Cerrado, as margens do Araguaia.

Atualmente, mesmo que de maneira reduzida, as atividades tradicionais de caça, pesca, coleta e agricultura ainda são mantidas pelo grupo que ao serem associadas às atividades de venda de artesanato e peixes e a prestação de serviços respondem pelo sustento da maior parte das famílias Karajá.

No entanto, como discutido, as situações de degradação ambiental no município, sobretudo, os desmatamentos, tem provocado a perda de importantes recursos da biodiversidade que comprometem diretamente a sustentabilidade física e cultural dos 
Karajá. Assim, as atividades de coleta destinadas a produção artesanal tem sido cada vez mais substituídas por outros recursos adquiridos no comercio local, estadual e nacional em função da perda da biodiversidade local, da restrição imposta pela propriedade privada, que impede os deslocamentos em busca de outros locais de coleta e pela própria delimitação e redução de seus territórios.

O turismo e a pecuária, como exposto, são as principais atividades econômicas do município e as que mais provocam impactos ambientais em Aruanã comprometendo os recursos naturais necessários ao sustento do grupo. $\mathrm{O}$ desmatamento gerado nas fazendas para produção das pastagens destinadas a criação de gado bovino aliado a perda, restrição e fragmentação do território Karajá impõe ao grupo enormes desafios de sobrevivência.

Viver nas áreas de confinamento nestas situações de degradação ambiental e pressão continua pelo uso constitui-se um desafio. No entanto, os Karajá mobilizam estratégias de resistência que alia de maneira criativa tradição indígena e cultura nãoindígena (re)elaborando caminhos para manterem sua etnicidade ligada ao território tradicional, o rio Araguaia e o Cerrado e por outro lado enfrentando os desafios do mundo competitivo impostos pela globalização.

Como entender a resistência histórica dos Karajá diante da pressão pelo uso e apropriação de seus territórios ao longo de tantos séculos? Como compreender a força da resistência indígena diante da perda do ambiente natural tornado artificializado através de gramíneas para sustento dos mais de 200 mil cabeças de gado bovino?

A integridade física e cultural ao terem suas bases abaladas gera também o movimento contrário, a resistência. É o olhar sobre as alternativas criadas pelo grupo ao longo dos anos, que talvez seja possível compreender o movimento de resistência e luta pela sobrevivência diante da perda do Cerrado e de seu território. São as estratégias políticas para estabelecer novas parcerias, são as alternativas de ampliar e diversificar a produção do artesanato para o comércio aquecido pelo turismo, são os deslocamentos em busca dos recursos variados para garantir a produção e o comercio das peças.

Tudo isso aponta que diante das perdas incontáveis da biodiversidade do Cerrado geradas pela intensidade do desmatamento no município de Aruanã, os indígenas reelaboram sua cultura e se reorganizam para sobreviverem diante da perda do Cerrado. O que sabemos é que há vários desafios estabelecidos para a manutenção da 
integridade física e cultural dos Karajá de Aruanã e dentre eles destacamos o crescimento da população indígena que, se por um lado representa avanço, por outro, impõe ao grupo novos desafios de sobrevivência nesse território restrito, fragmentado, e desmatado, além de permeado de interesses e conflitos.

\section{Referências Bibliográfica}

ALMEIDA, Maria Geralda. A captura do Cerrado e a precarização de territórios: um olhar sobre os sujeitos excluídos. In: ALMEIDA, Maria Geralda (Org.) Tantos Cerrados. Goiânia: Vieira, 2005, p. 321-347.

BARBOSA, Altair Sales. Andarilhos da Claridade: Os primeiros habitantes do Cerrado. Goiânia: Ed. UCG, 2002.

Ocupação indígena no sistema biogeográfico do Cerrado. In: GOMES, Horieste (Coord.). Universo do Cerrado.. Goiânia: Ed. UCG, 2008. V. 1

BARBOSA, Altair Sales. TEIXEIRA NETO, Antônio GOMES, Horieste. Geografia: Goiás-Tocantins. Goiânia: UFG, 2005.

BARREIRA, C.C.M.A. Região da estrada do boi: usos e abusos da natureza. Goiânia: UFG, 1997.

BENSUSAN, Nurit. A impossibilidade de ganhar a aposta e a destruição da natureza. In: BENSUSAN, Nurit (Org.) Seria melhor ladrilhar? Biodiversidade como, para que, porquê. Brasília: Editora Universidade de Brasília: Instituto Socioambiental, 2002.

DIEGUES, Antônio Carlos. Etnoconservação da natureza: enfoques alternativos. In (Org.). Etnoconservação: novos rumos para a conservação da natureza. São Paulo: Ed. HUCITEC, 2000, p. 1 - 46.

FERREIRA, Idelvone Ferreira. Bioma cerrado - um estudo das paisagens do Cerrado. 2003. 242 f. Tese (Doutorado em Geografia) - Universidade Estadual Paulista, Campus de Rio Claro, São Paulo, 2003.

HAESBART. Rogério. Identidades territoriais: entre a multiterritorialidade e a reclusão territorial (ou: do hibridismo cultural à essencialização das identidades). Disponível em: http://tercud.ulusofona.pt/GeoForum/Ficheiros/23GeoForum.pdf. Acesso em: 10 abr. 2009.

INSTITUTO BRASILEIRO DE GEOGRAFIA E ESTATÍSTICA

Disponível em: http://www.ibge.gov.br/home/. Acesso em: 20 ago. 2009.

LADEIRA, Maria Inês. Espaço Geográfico Guarani-Mbya: significado, constituição e uso. São Paulo: Edusp, 2008.

LIMA FILHO, Manuel Ferreira. Hetohokÿ: um rito Karajá. Goiânia: UCG, 1994, p. 183. 
LIMA FILHO, Manuel Ferreira. Karajá de Aruanã. In: MOURA, Marlene Castro Ossami de (Org.). Índios de Goiás: uma perspectiva histórico-cultural. Goiânia: Ed. da UCG/Ed. Vieira/Ed. Kelps, 2006.

LOIOLA, Sérgio Almeida. Por uma Geografia do passado distante - marcas pretéritas na paisagem como memória espacial das sociedades autóctones. 2007. $187 \mathrm{f}$. Dissertação (Mestrado em Geografia) - Instituto de Estudos Sócio-Ambientais, Universidade Federal de Goiás, Goiânia, 2007.

MOTTA. Olga Maria Fernandez. Os Karajá, o rio Araguaia e os outros: territorialidades em conflito. 2004. 95f. Dissertação (Mestrado em Geografia) Instituto de Estudos Sócio-Ambientais, Universidade Federal de Goiás, Goiânia, 2004.

OLIVEIRA, Ivanilton José de. Os Chapadões de(s)cerrados: a vegetação, o relevo e o uso das terras em Goiás e no Distrito Federal. In: ALMEIDA, Maria Geralda (Org.) Tantos Cerrados. Goiânia: Vieira, 2005.

PINTO, Miriam Plaza: DINIZ-FILHO, José Alexandre Felizola. Biodiversidade no Cerrado. In: ALMEIDA, Maria Geralda de. Tantos Cerrados. Goiânia: Vieira, 2005. p. 115-128.

PORTELA, Cristiane de Assis. Nem ressurgidos, nem emergentes: a resistência histórica dos Karajá de Buridina em Aruanã-GO (1980-2006). 2006. 233 f. (Dissertação de mestrado). Faculdade de Ciências Humanas e Filosofia, Universidade Federal de Goiás, Goiânia, 2006.

RATTS, Alecsandro José Prudêncio. Traços étnicos: espacialidades e culturas negras e indígenas. Fortaleza: Museu do Ceará: Secult, 2009.

RIBEIRO, Darcy. Os índios e a civilização - a integração das populações indígenas no Brasil Moderno. São Paulo: Companhia das Letras, 1996.

ROCHA, Leandro Mendes. O Estado e os índios: Goiás, 1850-1889. Goiânia: Ed. UFG, 1998.

SECRETARIA DO PLANEJAMENTO E DESENVOLVIMENTO. Estatísticas SEPIN dos municípios. Disponível em: http://www.seplan.go.gov.br/sepin/. Acesso em: 15 jul. 2009.

TORAL, André Amaral. Cosmologia e sociedade Karajá. 1992. 414 p. Dissertação (Mestrado em Antropologia Social), Museu Nacional, Universidade Federal do Rio de Janeiro, Rio de Janeiro, 1992, 1992. Vol. 1 e 2.

VALENTE, Cidney Rodrigues. Meio Ambiente - desafios a vencer. Secretaria Municipal de Meio Ambiente e Recursos Hídricos. Aruanã, Goiás: 2008.

Recebido para publicação em novembro de 2009 Aprovado para publicação em fevereiro de 2010 